Provided for non-commercial research and education use. Not for reproduction, distribution or commercial use.

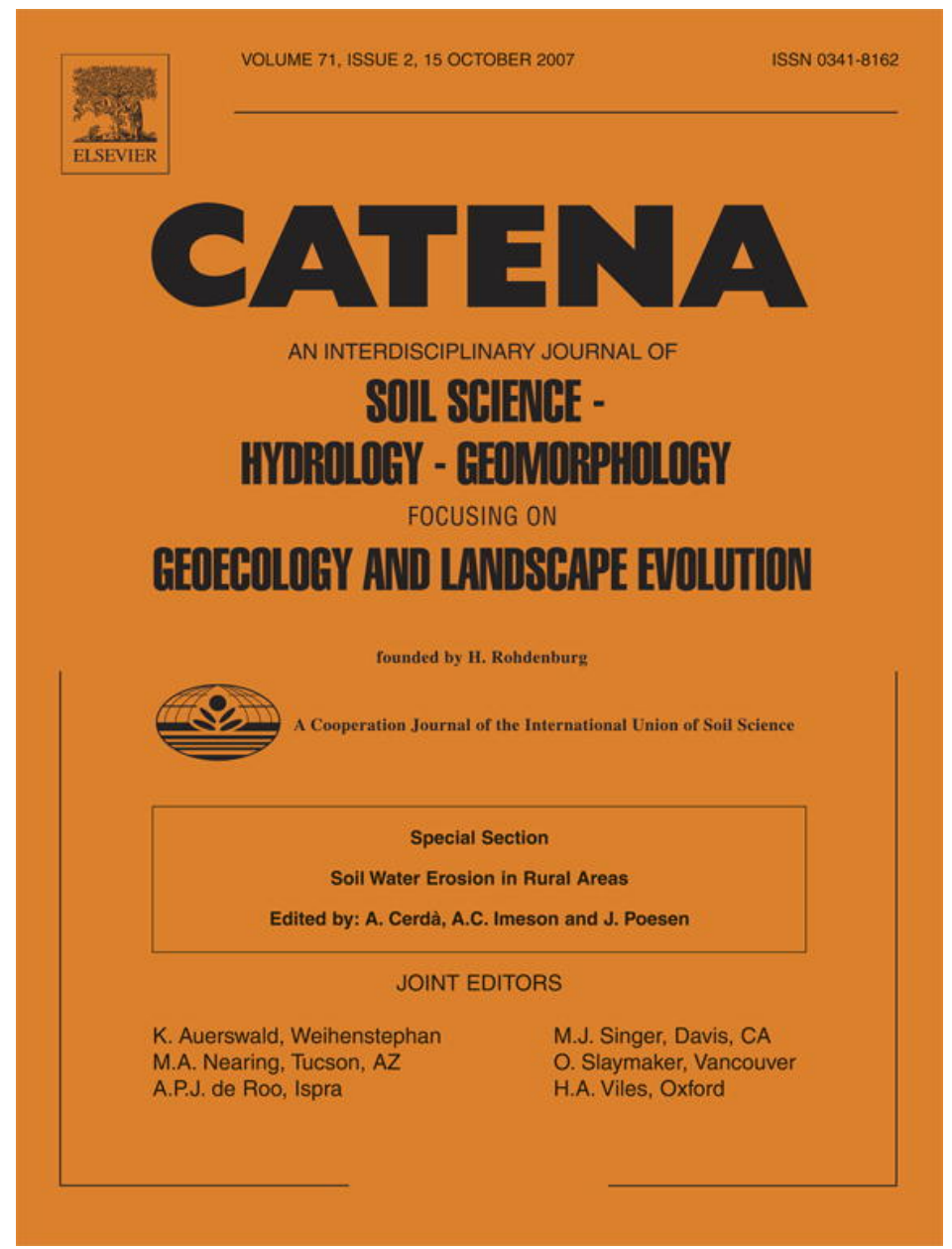

This article was published in an Elsevier journal. The attached copy

is furnished to the author for non-commercial research and education use, including for instruction at the author's institution, sharing with colleagues and providing to institution administration.

Other uses, including reproduction and distribution, or selling or licensing copies, or posting to personal, institutional or third party websites are prohibited.

In most cases authors are permitted to post their version of the article (e.g. in Word or Tex form) to their personal website or institutional repository. Authors requiring further information regarding Elsevier's archiving and manuscript policies are encouraged to visit: 


\title{
Runoff generation in a degraded Andean ecosystem: Interaction of vegetation cover and land use
}

\author{
Armando Molina ${ }^{\mathrm{a}, *}$, Gerard Govers ${ }^{\mathrm{a}}$, Veerle Vanacker ${ }^{\mathrm{b}, \mathrm{c}}$, Jean Poesen ${ }^{\mathrm{a}}$, \\ Edwin Zeelmaekers ${ }^{\mathrm{d}}$, Felipe Cisneros ${ }^{\mathrm{e}}$ \\ ${ }^{a}$ Physical and Regional Geography Research Group, Katholieke Universiteit Leuven, Celestijnenlaan 200E, B-3001 Heverlee, Belgium \\ ${ }^{\mathrm{b}}$ Department of Geography, University of Louvain, 3 Place Louis Pasteur, B-1348 Louvain-la-Neuve, Belgium \\ ${ }^{\mathrm{c}}$ Fonds de la Recherche Scientifique (FNRS), Rue d'Egmont 5, B-1000 Brussels, Belgium \\ d Department of Geography and Geology, Laboratory for Applied Geology and Mineralogy, Katholieke Universiteit Leuven, \\ Celestijnenlaan 200E, B-3001 Heverlee, Belgium \\ e Programa para el Manejo del Agua y del Suelo (PROMAS), Universidad de Cuenca, Av. 12 de abril s/n, Cuenca, Ecuador
}

Received 10 January 2007; received in revised form 22 March 2007; accepted 2 April 2007

\begin{abstract}
Tropical mountain regions are affected by rapid land use/-cover change, which may threaten their (eco-)hydrological functions. Although there is a growing interest in evaluating the effect of land use/-cover change on mountain hydrology, quantitative assessments of the impact of land use/cover on hydrological processes are hampered by the lack of field measurements characterizing runoff generation processes. In this paper, we present results from field experiments of rainfall runoff mechanisms in the southern Ecuadorian Andes. A rainfall simulator was used to quantify the hydrological response of distinct land use/-cover types to intense rainfall (about $40 \mathrm{~mm} / \mathrm{h}$ ). The rainfall runoff experiments indicate that degraded and abandoned land generate surface runoff within a few minutes after the start of the rainfall event. These lands have a very rapid and sharp hillslope hydrological response, as Hortonian overland flow is the dominant runoff generation mechanism. In contrast, surface runoff on arable and rangelands is rare, as their soils are characterized by a high infiltration capacity (i.e. $>29 \mathrm{~mm} / \mathrm{h}$ ). Our experiments provide evidence that runoff generation in degraded Andean ecosystems is mainly controlled by the surface vegetation cover and land management. When reducing the surface vegetation cover, the soil is increasingly affected by rapid hillslope runoff as the presence of large amounts of smectites in the outcropping soft rocks makes the material very prone to sealing and crusting, thereby enhancing runoff generation.
\end{abstract}

(C) 2007 Elsevier B.V. All rights reserved.

Keywords: Land use; Runoff generation; Vegetation cover; Degraded land; Andes; Rainfall simulation

\section{Introduction}

Mountain ecosystems fulfill essential hydrological functions, as they act as important water sources and regulators (Price, 1999; Viviroli and Weingartner, 2004). More than 50\% of the global population relies on water from mountain areas, for drinking, industry, agriculture, food preparation, hydropower, and many other purposes (Viviroli et al., 2003). Demographic growth and socio-economic development is accelerating land use/-cover change also in these fragile mountain environments, and may

\footnotetext{
* Corresponding author. Tel.: +32 16 326405; fax: +32 16322980 .

E-mail address: Armando.MolinaVerdugo@geo.kuleuven.be (A. Molina).
}

affect their main ecological and hydrological functions (Vanacker et al., 2003a; Harden, 2001). Understanding the hydrological response of mountain catchments with different land use/-cover histories allows one to assess the effect of land use/-cover change on surface runoff and sediment transport (Burch et al., 1987; Garcìa-Ruiz et al., 2005; Lopez-Moreno et al., 2006).

On mountain slopes, hydrological processes show large spatial and temporal variability. Runoff generation on mountain slopes often occurs as a complex combination of Hortonian and saturation overland flow, subsurface and return flow. The combination of intense rainfall, steep slope gradients and thin soils makes that overland flow is often an important component of runoff generation in these environments. Under specific meteorological circumstances, mountain catchments can respond very quickly 

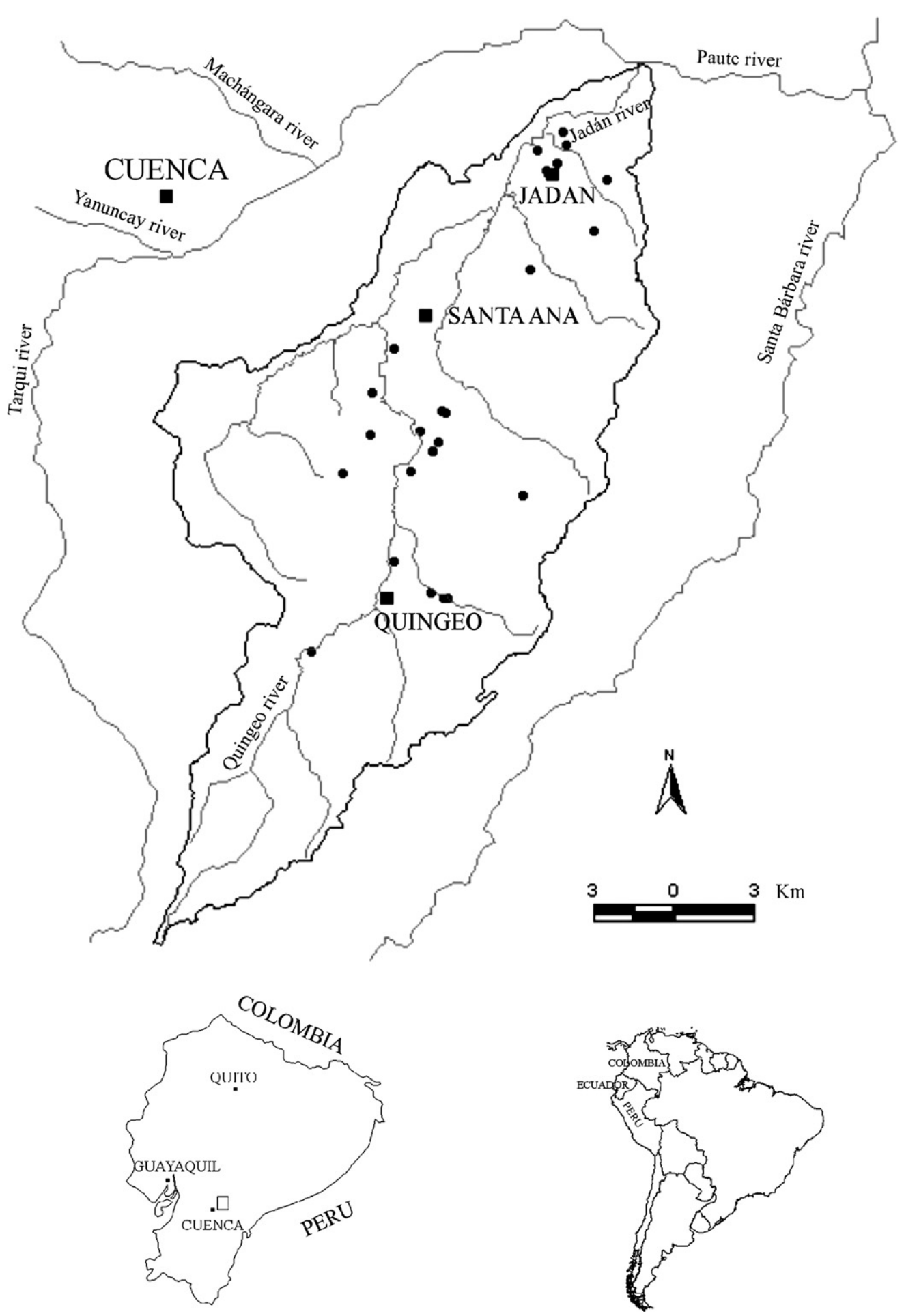

Fig. 1. Location of the study area in the Southern Ecuadorian Andes. The location of each site where simulated rainfall experiments were conducted in the Jadan catchment is indicated by a black dot.

with extreme peak discharges, which can induce destructive mountain torrents and floods (Weingartner et al., 2003).

The hydrological response of mountain catchments is controlled by many biotic and abiotic factors, such as chemical and physical surface and subsurface characteristics, vegetation type and density, and local topographical features, that are interacting with each other (Nahar et al., 2004; Begueria et al., 2006). Due to their steep gradient, mountain slopes are often characterized by rocky and shallow soils with highly variable runoff characteristics. On degraded sloping land, the topsoil generally consists of former subsoil material being exposed due to removal of the original surface horizon. These eroded soils are generally rich in clay and sandy loam, with a low soil organic matter content and limited vegetation cover. The infiltration rate is decreased by 
A
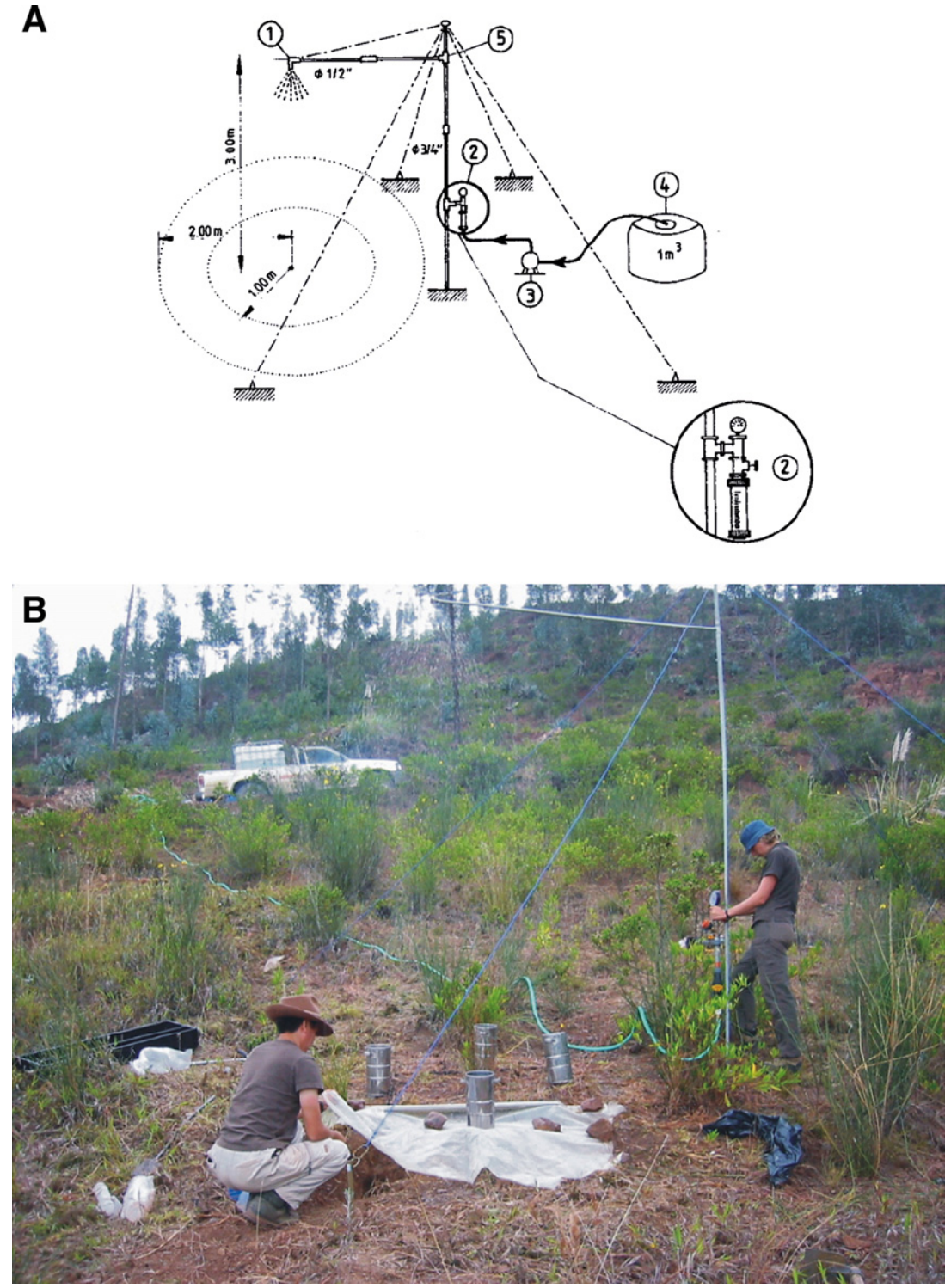

Fig. 2. (A) Plot layout and design of the rainfall simulator (after Poesen et al., 1995), 1: Nozzle Lechler 460.788 (36 mm/h), 2: Manometer 0-1 bar, Control valve, and Flowmeter Heinrichs 100-1000 1/h, 3: Water pump, 4: Water container $1 \mathrm{~m}^{3}$, 5: Horizontal mast containing the nozzle. (B) Rainfall simulation experiment in the field.

sealing and crusting of the topsoil due to physical disintegration of soil surface aggregates and physicochemical dispersion of soil clay particles (Janeau et al., 2003; Lado and Ben-Hur, 2004). Runoff generation on mountain slopes has also been shown to vary with land use (Harden, 1993). Vegetation protects the soil against raindrop impact and lowers its erosive capacity, enhances soil aggregation by incorporating organic matter to the soil, and reduces overland flow velocity and increases infiltration (e.g. Casermeiro et al., 2004; Molina et al., in press).

Change in any of these controlling factors due to climate and/ or land use/-cover change is likely to affect the runoff generation mechanisms. These changes can have large impacts on the surface and subsurface hydrology of mountain ecosystems. Although there is a growing interest in evaluating the effect of global change (such as climate and land use/-cover change) on mountain hydrology, quantitative assessments of the impact of climate change and land use/-cover change on hydrological processes are often hampered due to the lack of field measurements characterizing runoff generation processes (e.g. Gurtz et al., 1999). This is particularly the case for tropical mountain areas.

In this paper, we present results on rainfall runoff mechanisms in the southern Ecuadorian Andes obtained using simulated rainfall to quantify the hydrological response to heavy rainfall for fifty-five $1 \mathrm{~m}^{2}$ plots. For each plot, soil physical and chemical properties, and vegetation characteristics were analysed. The results allow us to analyse the role of biotic and abiotic factors controlling runoff generation on these mountain slopes. We particularly discuss the hydrological response of distinct land use/cover types by investigating the protective function of various land cover types to runoff generation. As the plot experiments cover the spatial variability in vegetation, soils and lithology that exists on agricultural land in this region, these results allow us to draw conclusions on human impact on runoff generation processes on mountain slopes in the Ecuadorian Andes. 


\section{Materials and methods}

\subsection{Study area}

Field research was carried out in the Jadan catchment, located at c. $20 \mathrm{~km}$ east of Cuenca in the southern Ecuadorian Andes (Fig. 1). The landscape is strongly dissected and has a relatively high drainage density. Slopes are generally steep: $34 \%$ of the catchment is composed of slopes steeper than $40 \%$, with the exception of some gently sloping land of less than $10 \%$ in alluvial valleys and upland areas (approx. $8 \%$ of the area). Mean annual rainfall measured at the station of CochapambaQuingeo, which is located in the Jadan catchment, is ca. $810 \mathrm{~mm}$, with the highest intensities during the rainy season between January and May. The maximum 24 h-rainfall intensity for a 5-year return period measured at this station is about $42 \mathrm{~mm} /$ day (Baculima et al., 1999).

The catchment's geology is mainly characterized by (i) Upper-Cretaceous dark gray stratified argillites (Yunguilla Formation) outcropping in the central part of the river valleys of the Jadan and Quingeo River, (ii) Upper-Eocene volcanics, lava flows and tuffs (Chinchin Formation) and conglomerates, sandstones and red and purple siltstones (Quingeo Formation) outcropping in the northeastern part of the catchment, and (iii) Upper-Miocene poorly consolidated and deeply weathered red volcanic airfall deposits (Tarqui Formation) outcropping in the upper southeastern and southwestern parts of the catchments (Hungerbühler et al., 2002). Soils have developed on these weathered volcanic and sedimentary rocks, and are generally very clayey. In the upper parts of the catchment, soils generally have a good internal drainage and high moisture content. In the middle and lower parts, soils are very shallow implicating low water holding capacity, and are poorly drained (Dercon et al., 1998).

In the past, agricultural activities were concentrated in the valleys and on gently sloping land : crops were produced on the fertile soils in the valleys while extensive cattle raising extended to the steeper slopes. Demographic growth and socio-economic development resulted in rapid land use/-cover change. Land reforms during the ' $60 \mathrm{~s}$ and ' 70 s resulted in a redistribution of landless people towards steep, degraded hillsides or the highlands. The agricultural frontier moved quickly upwards, whereby native forest has rapidly been converted into agricultural land (Vanacker et al., 2003b; Molina et al., in press). Since the late '70s, reforestation with exotic species, mainly Eucalyptus globulus and Pinus radiata, took place on highly degraded land and provided the smallholders an extra income by sale of firewood and timber (Vanacker et al., 2003a). After several decades of extremely high pressure on the land, we now observe a tendency towards land abandonment. Emigration to the USA and Europe are leading to rural land abandonment (Jokisch and Lair, 2002). Land abandonment is now resulting in (i) expansion of pastures due to colonization of abandoned cropland with natural pasture (Pennisetum clandestinum, Trifolium sp.), and (ii) acceleration of land degradation in areas where pasture could not colonize degraded agricultural fields or overgrazed land (Vanacker et al., 2005).

\subsection{Experimental design}

A rainfall simulator was used to characterize the runoff response of $1 \mathrm{~m}^{2}$ plots with different vegetation cover, soil type and lithology. As we were mainly interested in the effect of land use and management on runoff generation, we selected suitable sites on slopes having a slope gradient between 15 and $25 \%$. The plots were delimited with four fine steel plates of $1 \mathrm{~m}$ length, and runoff was collected from a saturated and compacted trench dug at the bottom of the runoff plot. A mobile sprinkler-type rainfall simulator was constructed (Fig. 2) and consisted of a downward-orientated axial-flow, wide-angle full cone nozzle (Poesen et al., 1990, 1995). A nozzle of type Lechler 460.788 was used to produce a rainfall intensity of about $40 \mathrm{~mm} / \mathrm{h}$ on average for an operation pressure of 0.39 bar. The rainfall simulator was located so that the rainfall was centralized above the plot. The simulator is designed to wet a total target area of $2 \mathrm{~m}$ radius. The water supply system consisted of a $1 \mathrm{~m}^{3}$ water container from where water was pumped to the flowmeter. The operating water pressure was continuously monitored and kept constant. Four rain gauges located at each side of the runoff plot were used to calculate the effective rainfall intensity over the plot.

\subsection{Rainfall simulation experiments}

A total of fifty-five experiments were conducted in the summer of 2004 and 2005 in order to measure the hydrological response of different land use types to heavy rainfall. We distinguished four land use types in the rural areas, each one having a distinct vegetation cover and land management (Table 1). The

\begin{tabular}{|c|c|c|}
\hline Land use class & $\begin{array}{l}\text { Number of } \\
\text { experiments }\end{array}$ & Characteristics \\
\hline Degraded land & 37 & $\begin{array}{l}\text { Removal of topsoil material by intense water } \\
\text { erosion, leading to exposure of subsoil or } \\
\text { weathered bedrock. } \\
\text { Low vegetation cover, consisting of } \\
\text { Cynodon dactylon, Holcus lanatus, } \\
\text { Cortaderia rudiuscula, Festuca megalura, } \\
\text { Baccharis polyantha, Pennisetum } \\
\text { clandestinum and Spartium junceum. }\end{array}$ \\
\hline Rangeland & 5 & $\begin{array}{l}\text { Soils with high infiltration capacity due to } \\
\text { the presence of macropores. } \\
\text { Good protective vegetation cover, consisting } \\
\text { of perennial grasses such as Pennisetum } \\
\text { clandestinum and Trifolium sp., used for } \\
\text { livestock. }\end{array}$ \\
\hline Arable land & 8 & $\begin{array}{l}\text { Well-drained and structured soils with high } \\
\text { infiltration capacity due to ploughing and } \\
\text { presence of macropores. } \\
\text { Fallow land that was recently harvested or } \\
\text { ploughed. Covered by crop residues (corn, } \\
\text { beans, potatoes and vegetables) and weeds. }\end{array}$ \\
\hline Abandoned land & 5 & $\begin{array}{l}\text { Compacted, eroded and poorly drained soils } \\
\text { with low infiltration capacity. } \\
\text { Cropland that was abandoned for a long time } \\
\text { ( }>3 \text { years), covered with natural grasses and } \\
\text { used for grazing. }\end{array}$ \\
\hline
\end{tabular}


Table 2

Summary of rainfall simulation experiments, with indication of their physical and chemical soil characteristics, vegetation cover $(\mathrm{VC})$, textural class $(\mathrm{SL}=\mathrm{Sandy}$ loam, $\mathrm{SC}=$ Silty clay, $\mathrm{L}=$ loam, $\mathrm{SIL}=$ Silt loam, $\mathrm{CL}=$ Clay loam, $\mathrm{SCL}=$ Sandy clay loam, $\mathrm{SICL}=$ Silty clay loam and $\mathrm{C}=\mathrm{Clay})$, antecedent moisture content $(\mathrm{AMC})$, land use type $(\mathrm{D}=$ Degraded land, $\mathrm{R}=$ Rangeland, $\mathrm{AR}=$ Arable land and $\mathrm{AB}=\mathrm{Abandoned}$ land) and lithology $(\mathrm{ARG}=\mathrm{Argillites}$, $\mathrm{VA}=\mathrm{Volcanic}$ ash deposits, and $\mathrm{AS}=$ Argillaceous silt- and sandstone)

\begin{tabular}{|c|c|c|c|c|c|c|c|c|c|c|c|c|c|c|c|c|c|}
\hline \multirow[t]{2}{*}{ Plot } & \multirow{2}{*}{$\begin{array}{l}\text { Total } \\
\text { rainfall } \\
\text { RI } \\
\mathrm{mm}\end{array}$} & \multirow{2}{*}{$\begin{array}{l}\text { Total } \\
\text { runoff } \\
\frac{\mathrm{RR}}{\mathrm{mm}}\end{array}$} & \multirow{2}{*}{$\begin{array}{l}\text { Steady-state } \\
\text { runoff } \\
\text { coefficient } \\
\%\end{array}$} & \multirow{2}{*}{$\begin{array}{l}\text { Cumulative } \\
\text { runoff } \\
\text { coefficient } \\
\%\end{array}$} & \multirow{2}{*}{$\begin{array}{l}\mathrm{VC} \\
\frac{}{\%}\end{array}$} & \multirow{2}{*}{$\begin{array}{l}\text { Organic } \\
\text { matter } \\
\%\end{array}$} & \multirow{2}{*}{$\begin{array}{l}\text { Sand } \\
\overline{\%}\end{array}$} & \multirow{2}{*}{$\begin{array}{l}\text { Silt } \\
\frac{\%}{\%}\end{array}$} & \multirow{2}{*}{$\begin{array}{l}\text { Clay } \\
\overline{\%}\end{array}$} & \multirow[t]{2}{*}{ Texture } & \multirow[t]{2}{*}{$\mathrm{pH}$} & E.C. & $\begin{array}{l}\text { Bulk } \\
\text { density }\end{array}$ & $\mathrm{AMC}$ & $\begin{array}{l}\text { Time to } \\
\text { runoff }\end{array}$ & $\begin{array}{l}\text { Land } \\
\text { use }\end{array}$ & Lithology \\
\hline & & & & & & & & & & & & $\mathrm{dS} / \mathrm{m}$ & $\mathrm{mg} / \mathrm{cm}^{3}$ & $\%$ & $\min$ & & \\
\hline 2 & 31 & 8 & 32 & 25 & 35 & 0.8 & 52 & 30 & 18 & SL & 7.5 & 0.28 & 1.66 & 7.9 & 15.3 & $\mathrm{D}$ & $\mathrm{ARG}$ \\
\hline 3 & 33 & 1 & 6 & 4 & 83 & 1.8 & 53 & 33 & 14 & SL & 6.4 & 0.37 & 1.75 & 9.1 & 10.5 & $\mathrm{D}$ & $\mathrm{ARG}$ \\
\hline 4 & 34 & 5 & 23 & 15 & 12 & 1.6 & 9 & 41 & 50 & $\mathrm{SC}$ & 4.7 & 0.09 & 1.22 & 33.4 & 23.7 & $\mathrm{D}$ & VA \\
\hline 5 & 33 & 7 & 27 & 21 & 10 & 0.7 & 7 & 41 & 52 & $\mathrm{SC}$ & 4.8 & 0.09 & 1.14 & 36.6 & 17.0 & $\mathrm{D}$ & VA \\
\hline 6 & 35 & 13 & 44 & 37 & 6 & 0.0 & 60 & 30 & 10 & SL & 7.7 & 0.22 & 2.01 & 8.7 & 5.8 & $\mathrm{D}$ & AS \\
\hline 7 & 20 & 15 & 84 & 73 & 4 & 0.3 & 60 & 33 & 7 & SL & 7.9 & 0.23 & 1.86 & 7.0 & 2.8 & $\mathrm{D}$ & AS \\
\hline 8 & 28 & 10 & 51 & 34 & 0 & 0.2 & 28 & 46 & 26 & $\mathrm{~L}$ & 5.6 & 0.10 & 1.24 & 35.7 & 16.9 & $\mathrm{D}$ & VA \\
\hline 9 & 29 & 6 & 27 & 20 & 72 & 0.2 & 21 & 55 & 24 & SIL & 5.4 & 0.11 & 1.05 & 37.4 & 8.8 & $\mathrm{D}$ & VA \\
\hline 10 & 30 & 14 & 64 & 45 & 10 & 0.2 & 45 & 36 & 19 & $\mathrm{~L}$ & 6.4 & 0.20 & 1.68 & 13.9 & 9.0 & $\mathrm{D}$ & $\mathrm{ARG}$ \\
\hline 11 & 30 & 7 & 35 & 24 & 29 & 0.2 & 46 & 31 & 23 & $\mathrm{~L}$ & 5.9 & 0.18 & 1.50 & 15.3 & 10.8 & $\mathrm{D}$ & $\mathrm{ARG}$ \\
\hline 12 & 42 & 16 & 49 & 38 & 18 & 0.0 & 50 & 37 & 13 & $\mathrm{~L}$ & 7.1 & 0.30 & 1.64 & 15.0 & 6.9 & $\mathrm{D}$ & $\mathrm{ARG}$ \\
\hline 13 & 32 & 22 & 81 & 70 & 31 & 0.3 & 32 & 39 & 29 & CL & 6.5 & 0.32 & 1.51 & 14.7 & 4.3 & $\mathrm{D}$ & $\mathrm{ARG}$ \\
\hline 14 & 25 & 15 & 80 & 61 & 6 & 0.2 & 48 & 40 & 12 & $\mathrm{~L}$ & 6.9 & 0.09 & 1.93 & 6.0 & 7.8 & $\mathrm{D}$ & AS \\
\hline 16 & 31 & 2 & 11 & 8 & 86 & 1.4 & 44 & 28 & 28 & CL & 6.2 & 0.25 & 1.37 & 16.9 & 6.5 & $\mathrm{R}$ & $\mathrm{ARG}$ \\
\hline 18 & 26 & 5 & 25 & 20 & 64 & 4.6 & 33 & 36 & 31 & CL & 6.4 & 0.35 & 1.58 & 14.7 & 5.7 & $\mathrm{D}$ & VA \\
\hline 19 & 27 & 15 & 79 & 55 & 43 & 0.9 & 51 & 26 & 23 & SCL & 7.2 & 0.34 & 1.45 & 19.2 & 8.6 & $\mathrm{D}$ & VA \\
\hline 20 & 23 & 15 & 75 & 65 & 47 & 1.4 & 33 & 56 & 11 & SIL & 5.7 & 0.17 & 1.58 & 14.7 & 4.8 & $\mathrm{AB}$ & AS \\
\hline 22 & 31 & 19 & 70 & 59 & 20 & 2.2 & 12 & 53 & 35 & SICL & 4.8 & 0.14 & 1.19 & 25.4 & 3.9 & $\mathrm{D}$ & $\mathrm{ARG}$ \\
\hline 23 & 29 & 14 & 58 & 47 & 0 & 0.3 & 8 & 82 & 10 & SIL & 4.8 & 0.09 & 1.12 & 37.6 & 8.3 & $\mathrm{D}$ & $\mathrm{ARG}$ \\
\hline 25 & 32 & 24 & 86 & 77 & 38 & 2.7 & 31 & 44 & 25 & $\mathrm{~L}$ & 4.7 & 0.12 & 1.37 & 13.8 & 3.0 & $\mathrm{D}$ & AS \\
\hline 26 & 28 & 12 & 50 & 42 & 30 & 1.3 & 26 & 42 & 32 & CL & 6.6 & 0.27 & 1.43 & 15.7 & 5.5 & $\mathrm{D}$ & AS \\
\hline 27 & 34 & 12 & 42 & 34 & 29 & 1.3 & 24 & 50 & 26 & CL & 6.1 & 0.28 & 1.58 & 16.9 & 6.1 & $\mathrm{D}$ & AS \\
\hline 28 & 27 & 3 & 15 & 13 & 11 & 1.7 & 32 & 45 & 23 & $\mathrm{~L}$ & 6.6 & 1.05 & 1.52 & 16.7 & 2.9 & AR & AS \\
\hline 29 & 33 & 2 & 5 & 5 & 25 & 2.3 & 40 & 41 & 19 & $\mathrm{~L}$ & 7.1 & 0.67 & 1.64 & 17.6 & 4.6 & AR & AS \\
\hline 30 & 38 & 2 & 6 & 5 & 15 & 2.0 & 37 & 42 & 21 & $\mathrm{~L}$ & 6.8 & 0.86 & 1.64 & 14.4 & 5.7 & $\mathrm{AR}$ & AS \\
\hline 31 & 22 & 0 & 0 & 0 & 8 & 2.6 & 36 & 40 & 24 & $\mathrm{~L}$ & 7.0 & 1.20 & 1.33 & 24.6 & 16.3 & AR & AS \\
\hline 32 & 30 & 0 & 1 & 1 & 7 & 2.7 & 34 & 41 & 25 & $\mathrm{~L}$ & 6.5 & 1.09 & 1.34 & 27.4 & 5.9 & AR & AS \\
\hline 33 & 38 & 3 & 10 & 8 & 9 & 2.7 & 35 & 41 & 24 & $\mathrm{~L}$ & 6.7 & 1.15 & 1.32 & 26.5 & 7.6 & AR & AS \\
\hline 35 & 32 & 9 & 36 & 28 & 88 & 6.5 & 12 & 54 & 34 & SICL & 6.7 & 0.66 & 1.24 & 33.8 & 6.5 & $\mathrm{AB}$ & AS \\
\hline 36 & 26 & 0 & 0 & 0 & 100 & 5.2 & 55 & 34 & 11 & SL & 6.0 & 0.53 & 1.45 & 24.3 & 45.0 & $\mathrm{R}$ & $\mathrm{ARG}$ \\
\hline 37 & 24 & 0 & 0 & 0 & 99 & 5.0 & 48 & 40 & 12 & $\mathrm{~L}$ & 6.0 & 0.53 & 1.27 & 30.4 & 9.0 & $\mathrm{R}$ & $\mathrm{ARG}$ \\
\hline 38 & 30 & 1 & 9 & 5 & 100 & 9.7 & 59 & 26 & 15 & SL & 4.5 & 0.20 & 0.71 & 55.2 & 22.1 & $\mathrm{R}$ & VA \\
\hline 39 & 31 & 2 & 14 & 7 & 99 & 6.6 & 54 & 28 & 18 & SL & 4.5 & 0.18 & 0.69 & 87.8 & 23.0 & $\mathrm{R}$ & VA \\
\hline 40 & 26 & 0 & 2 & 2 & 74 & 1.6 & 19 & 38 & 43 & $\mathrm{C}$ & 6.2 & 0.36 & 1.13 & 30.1 & 8.9 & AR & VA \\
\hline 41 & 30 & 1 & 6 & 4 & 62 & 1.6 & 28 & 43 & 29 & CL & 6.6 & 0.48 & 1.21 & 30.1 & 6.7 & AR & VA \\
\hline 42 & 31 & 16 & 63 & 52 & 0 & 0.2 & 40 & 32 & 28 & CL & 7.1 & 0.20 & 1.30 & 22.8 & 11.6 & $\mathrm{D}$ & VA \\
\hline 43 & 32 & 17 & 76 & 53 & 0 & 0.2 & 40 & 32 & 28 & CL & 7.1 & 0.20 & 1.30 & 22.8 & 9.0 & $\mathrm{D}$ & VA \\
\hline 44 & 33 & 24 & 86 & 73 & 5 & 0.2 & 39 & 28 & 33 & CL & 6.8 & 0.19 & 1.30 & 23.6 & 3.1 & $\mathrm{D}$ & VA \\
\hline 45 & 36 & 2 & 13 & 5 & 72 & 3.2 & 25 & 32 & 43 & $\mathrm{C}$ & 5.9 & 0.21 & 1.30 & 17.3 & 21.1 & $\mathrm{D}$ & VA \\
\hline 46 & 31 & 23 & 75 & 74 & 0 & 0.4 & 33 & 38 & 29 & CL & 5.8 & 0.13 & 1.66 & 17.9 & 1.5 & $\mathrm{D}$ & $\mathrm{ARG}$ \\
\hline 47 & 36 & 21 & 75 & 60 & 27 & 0.4 & 37 & 38 & 25 & $\mathrm{~L}$ & 5.8 & 0.16 & 1.66 & 13.8 & 2.8 & $\mathrm{D}$ & ARG \\
\hline 48 & 29 & 21 & 76 & 72 & 0 & 0.4 & 36 & 34 & 30 & CL & 5.8 & 0.13 & 1.66 & 15.9 & 0.8 & $\mathrm{D}$ & $\mathrm{ARG}$ \\
\hline 49 & 28 & 17 & 67 & 61 & 0 & 0.0 & 36 & 32 & 32 & CL & 7.1 & 0.15 & 1.32 & 16.5 & 1.0 & $\mathrm{D}$ & AS \\
\hline 50 & 29 & 12 & 46 & 40 & 0 & 0.0 & 36 & 32 & 32 & CL & 7.1 & 0.16 & 1.32 & 16.5 & 3.0 & $\mathrm{D}$ & AS \\
\hline 51 & 30 & 16 & 56 & 54 & 0 & 0.0 & 36 & 32 & 32 & CL & 7.1 & 0.15 & 1.32 & 16.5 & 1.1 & $\mathrm{D}$ & AS \\
\hline 52 & 30 & 18 & 67 & 58 & 54 & 1.8 & 37 & 28 & 35 & CL & 6.5 & 0.29 & 1.34 & 15.6 & 1.3 & $\mathrm{AB}$ & VA \\
\hline 53 & 28 & 25 & 98 & 90 & 28 & 3.5 & 37 & 28 & 35 & CL & 6.3 & 0.32 & 1.34 & 15.6 & 1.0 & $\mathrm{AB}$ & VA \\
\hline 54 & 24 & 9 & 42 & 37 & 59 & 2.7 & 40 & 28 & 32 & CL & 6.4 & 0.31 & 1.34 & 15.6 & 2.0 & $\mathrm{AB}$ & VA \\
\hline 55 & 28 & 17 & 66 & 62 & 0 & 0.3 & 15 & 34 & 51 & $\mathrm{C}$ & 5.8 & 0.12 & 1.63 & 16.7 & 2.2 & $\mathrm{D}$ & $\mathrm{ARG}$ \\
\hline 56 & 39 & 22 & 65 & 57 & 0 & 0.3 & 56 & 22 & 22 & SCL & 5.8 & 0.12 & 1.63 & 3.0 & 0.6 & $\mathrm{D}$ & ARG \\
\hline 57 & 30 & 9 & 40 & 28 & 33 & 1.9 & 21 & 34 & 45 & $\mathrm{C}$ & 5.8 & 0.19 & 1.63 & 14.7 & 3.8 & $\mathrm{D}$ & ARG \\
\hline 58 & 33 & 16 & 52 & 48 & 2 & 1.0 & 36 & 26 & 38 & CL & 6.5 & 0.19 & 1.43 & 13.6 & 0.5 & $\mathrm{D}$ & VA \\
\hline 59 & 32 & 20 & 69 & 64 & 0 & 1.0 & 36 & 26 & 38 & CL & 6.5 & 0.19 & 1.43 & 13.6 & 2.0 & $\mathrm{D}$ & VA \\
\hline 60 & 34 & 14 & 44 & 42 & 0 & 1.0 & 36 & 26 & 38 & CL & 6.5 & 0.19 & 1.43 & 13.6 & 2.0 & $\mathrm{D}$ & VA \\
\hline 61 & 33 & 33 & 100 & 100 & 0 & 1.0 & 47 & 32 & 21 & $\mathrm{~L}$ & 4.7 & 0.09 & 1.44 & 3.4 & 0.4 & $\mathrm{D}$ & AS \\
\hline
\end{tabular}


Table 3

Pearson correlation coefficient between the cumulative runoff coefficients and each one of the explanatory catchment variables

\begin{tabular}{lrr}
\hline Explanatory variables & Correlation coefficients & $p$-value \\
\hline Vegetation cover & -0.53 & $<.0001$ \\
Organic matter & -0.46 & 0.0004 \\
Bulk density & 0.29 & 0.0304 \\
Electrical conductivity & -0.54 & $<.0001$ \\
pH & 0.03 & 0.9830 \\
Sand & 0.03 & 0.8393 \\
Silt & -0.10 & 0.4510 \\
Clay & 0.06 & 0.6558 \\
Simulated rainfall & -0.02 & 0.8979 \\
Antecedent moisture content & -0.43 & 0.0010 \\
\hline
\end{tabular}

surface vegetation cover of each plot was assessed visually from vertical photographs of the soil surface, taken at about $1.5 \mathrm{~m}$ height. All photographs were focused on a wooden frame with grid cells of 0.10 by $0.10 \mathrm{~m}$ (100 nodes) that was placed on the surface. The overall vegetation cover was then calculated as the percentage of nodes overlying vegetation fragments.

The effective rainfall intensity during the experiments is $41 \pm$ $6 \mathrm{~mm} / \mathrm{h}$, which corresponds with the maximum $24 \mathrm{~h}$ rainfall intensity for a 5-year return period. We simulated heavy rainfall during $45 \mathrm{~min}$. The effective rainfall intensities varied slightly between plots due to local wind conditions (Table 2). As soils in the Jadan catchment are very clayey, the steady-state infiltration capacity was reached within the first 30 min of rainfall simulation.

\subsection{Soil characteristics}

Before and after the experiments three representative soil samples were taken in or near the plot using a Kopecky core sampler at a depth of 5 to $15 \mathrm{~cm}$ below the surface to determine their bulk density and gravimetric soil moisture content. One additional soil sample was taken per plot to characterize its physical and chemical properties, in particular soil texture, soil organic matter, $\mathrm{pH}$, and electrical conductivity. Two representative samples of the dominant lithologies (argillites, volcanic ash deposits, and weathered silt- and sandstones) were taken to characterize their (clay) mineralogy. The analysis of the mineralogy is based on (i) a bulk analysis and (ii) a clay extraction.

The bulk mineralogy was analyzed following the method of Środoń et al. (2001). This method is based on grounding the bulk material together with a $\mathrm{ZnO}$ internal standard to $\mu \mathrm{m}$ grain size by the use of a McCrone Micronizing Mill. The resulting powder was then analyzed by X-ray diffraction. The data analysis was done by the QUANTA software. This procedure allows to determine the quantitative composition of a sample for all non-clays and the clay minerals assembled in maximum 6 groups and is currently the most accurate way to determine the overall quantitative composition of clay-bearing samples (Omotoso et al., 2006). The results are presented in Table 4, and the clay minerals were assembled in 3 groups: kaolinite, chlorite and 2:1 dioctahedral clays and micas (illite/smectite/illite-smectite/micas). To obtain more detailed information about the clay minerals it was necessary to extract them from the bulk sediment. Hereto all cementing agents (carbonates, organic matter and Fe-oxides) were removed following the procedure of Jackson (1975). After these treatments the fractions $<0.2 \mu \mathrm{m}$ and $<2 \mu \mathrm{m}$ were separated by centrifugation. Oriented sedimentation slides and smearmounts were made of these fractions and registered by a X-ray diffractometer in different states (air-dry, ethylene glycol saturated, heated to $300{ }^{\circ} \mathrm{C} / 1 \mathrm{~h}$ and $550{ }^{\circ} \mathrm{C} / 1 \mathrm{~h}$ ) to permit standard clay identification techniques (e.g. Moore and Reynolds, 1997). No attempt was made to differentiate between smectite and vermiculite or smectitic and vermiculitic mixed-layering, therefore in this paper 'smectite' refers to all swelling clay minerals.

\subsection{Statistical analysis of factors controlling runoff generation}

The dependency of runoff coefficients on vegetation cover, lithology, land use and soil physical and chemical properties

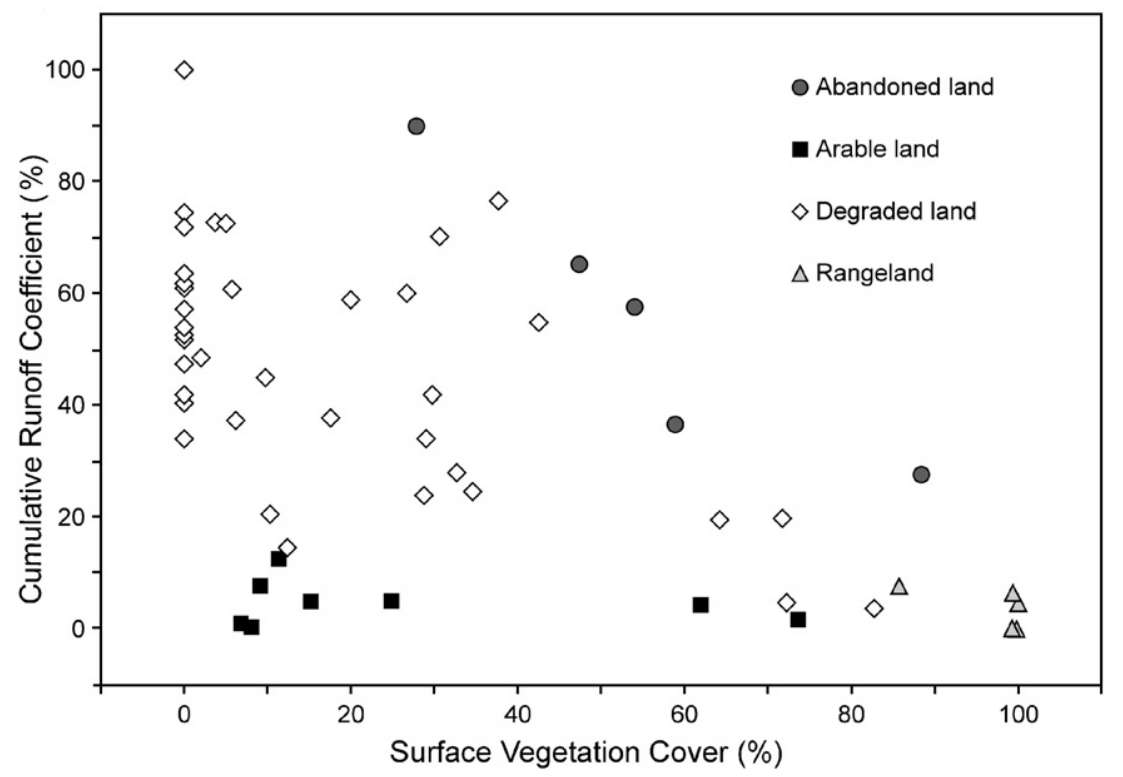

Fig. 3. Scatterplot of the cumulative runoff coefficient (RC) against the surface vegetation cover for different land use types. 
was tested using statistical analyses. The data set contains for each runoff experiment eleven numerical (one response and ten explanatory) and two categorical variables (Table 2). A Pearson correlation analysis was performed on each pair of response and explanatory variables to detect strength and type of association. Regression techniques were used to explain the observed variability in runoff generation. First, simple linear regression models were fitted to the pairs of response-explanatory variables with the highest correlation coefficients. Second, a multiple regression model was fitted, which contains quantitative and qualitative predictor variables. An indicator variable taking the value of 0 (absence) vs. 1 (presence) was used to incorporate the qualitative variable into the regression model. Additionally, an interaction term was introduced.

\section{Results}

The hydrological response of the experimental plots to rainfall was quantified by calculating the steady-state and cumulative runoff coefficient of each plot after $45 \mathrm{~min}$ of simulated rainfall (Table 2). Here, we present the results of the statistical analysis of the factors controlling runoff generation with the cumulative runoff coefficient (RC) as response variable. The latter was calculated as following:

$\mathrm{RC}=(\mathrm{RR} / \mathrm{RI}) * 100$,

where RC (\%) is the cumulative runoff coefficient, RR ( $\mathrm{mm})$ is the total runoff and RI ( $\mathrm{mm})$ is the total rainfall after $45 \mathrm{~min}$ of simulated rain. It is important to note that similar results are obtained when analysing the factors controlling steady-state runoff, as the steady-state and cumulative runoff coefficient are highly correlated (sample correlation coefficient, $r=0.98$, $n=55$ ) that vegetation cover, soil organic matter and soil electrical conductivity are moderately correlated to runoff coefficients, and that bulk density is weakly correlated. Other variables such as rainfall intensity, soil texture, $\mathrm{pH}$ and antecedent moisture content are not significantly related to the runoff coefficients (Table 3 ). Simple regression analyses between the predictor variable (cumulative runoff coefficient) and each one of the significant numerical explanatory variables indicated that surface vegetation cover has the highest predictive power (coefficient of determination, $R^{2}=0.28$ ), and exerts the strongest influence on runoff generation (Fig. 3). Organic matter has the second highest predictive power $\left(R^{2}=0.21\right)$, followed by the bulk density $\left(R^{2}=0.08\right)$. Although the electrical conductivity has some explanatory power, it was not included in further analyses as the soil analyses indicated very low amounts of total soluble salts, and the inexistence of sodium in the soil. Therefore, soil salinity has here no effect on the soil physical properties in terms of flocculation and dispersion. The relation between the runoff coefficients and the categorical explanatory variables (land use, and lithology) is shown in Fig. 4. There is a clear difference in runoff generation between the different land use classes. Degraded and abandoned lands (i.e. land that has not been cultivated for at least 3 consecutive years, Table 1) clearly generate more runoff than arable land or rangeland (Fig. 4A). They produce on
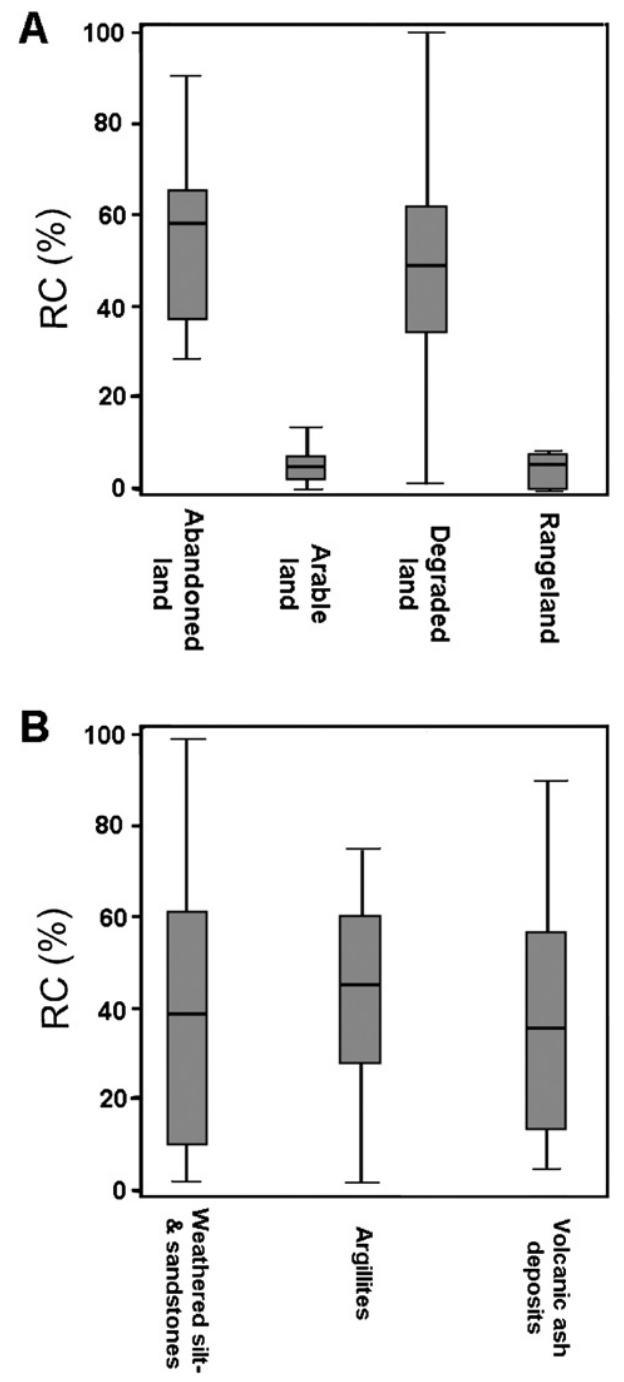

Fig. 4. Rainfall runoff response, expressed by the cumulative runoff coefficient (RC, i.e. the percentage of the total rainfall that appears as surface runoff), for different (A) land use types and (B) lithologies. In the box-and-whisker diagrams, the central rectangle spans the first quartile to the third quartile; the segment inside the rectangle shows the median and the whiskers above and below the box show the locations of the minimum and maximum.

average 12 times more cumulative runoff than the latter two land use classes. We observe no difference in runoff response between various lithologies (Fig. 4B).

The statistical model predicting the runoff response contains one numerical (vegetation cover) and one categorical (land use) explanatory variable and their interaction effects. None of the remaining explanatory variables (soil organic matter and bulk density) adds sufficient explanatory power to be included as a separate variable in a multiple regression model. The following equation was obtained by fitting a stepwise linear regression model to the data $\left(n=55, R^{2}=0.61\right)$ :

$$
\mathrm{RC}=5.5-0.02 X_{1}+52.0 X_{2}-0.4 X_{1} X_{2}
$$

where $X_{1}$ is the surface vegetation cover (\%), $X_{2}$ is the land use class (if degraded land or abandoned fields, then $X_{2}=1$; otherwise $X_{2}=0$ ). At the plot scale, more than $60 \%$ of the observed variance 
in runoff generation can be explained by a combination of land use class and surface vegetation cover. The vegetation cover has a direct physical impact on runoff generation, as plant and residue cover protect the soil from raindrop impact and splash, tend to slow down surface runoff and allow excess surface water to infiltrate. Land use indirectly affects runoff generation, which points to the impact of land management on runoff generation.

\section{Discussion}

\subsection{Importance of soil mineralogy for runoff generation}

Our results indicate that, in the absence of a protective vegetation cover, the rainfall runoff response in the Jadan catchment is very quick and runoff coefficients are high (Fig. 5). Soils developed on all three dominant lithologies are very clay-rich, and over $50 \%$ of the soil material consists of clay minerals. More than half (in total clays) of these clay minerals predominantly consist of 2:1 dioctahedral clays, mainly smectites and mixedlayered minerals containing smectite (Table 4). The presence of large amounts of swelling clays in all outcropping lithologies of the Jadan catchment is certainly enhancing runoff generation. Soils that contain smectite are unstable, prone to sealing and crusting by raindrop impact (Lado and Ben-Hur, 2004). During rainfall simulation experiments, sealing and crusting was observed regularly. In the absence of protective vegetation cover, surface sealing started shortly after the start of the rainfall simulation. This leads to physico-chemical dispersion of soil clay
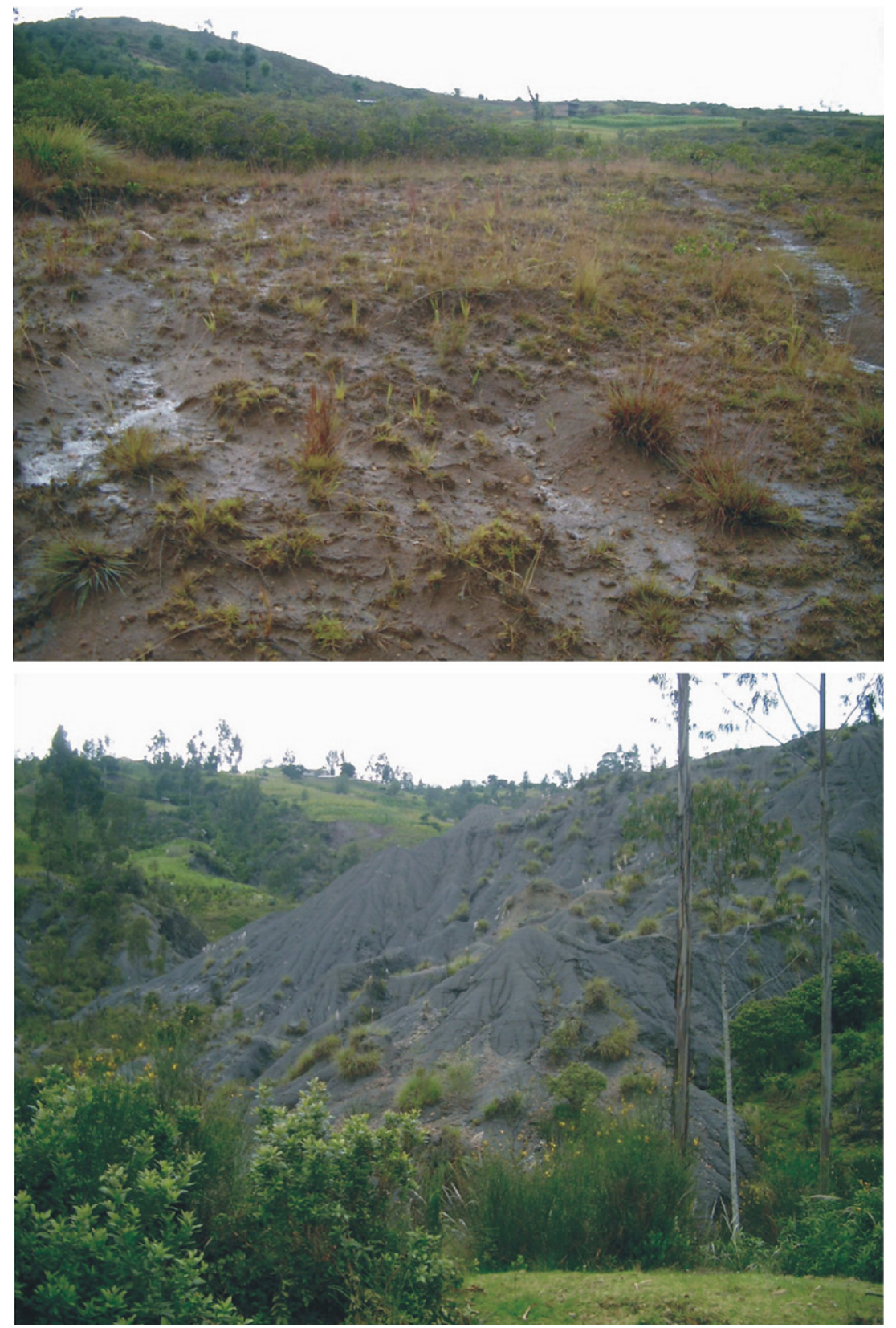

Fig. 5. Surface runoff on degraded land starts shortly after the onset of rain. The top picture illustrates on-site Hortonian runoff mechanisms, and the bottom picture illustrates the connectivity between runoff patches by rills and gullies. 
Table 4

Clay mineralogy of the dominant lithologies (argillites, argillaceous sandstone/siltstone and volcanic deposits)

\begin{tabular}{|c|c|c|c|c|c|c|}
\hline & $\begin{array}{l}\text { Argillaceous } \\
\text { sandstone/siltstone }\end{array}$ & $\begin{array}{l}\text { Argillaceous } \\
\text { sandstone/siltstone }\end{array}$ & $\begin{array}{l}\text { Volcanic } \\
\text { deposits }\end{array}$ & $\begin{array}{l}\text { Volcanic } \\
\text { deposits }\end{array}$ & Argillites & Argillites \\
\hline & $\%$ & $\%$ & $\%$ & $\%$ & $\%$ & $\%$ \\
\hline \multicolumn{7}{|l|}{ Non-clays } \\
\hline Quartz & 24 & 26 & 3 & 7 & 28 & 26 \\
\hline Amorphous matter & 2 & 4 & 13 & 8 & & 3 \\
\hline Goethite & 3 & 2 & 2 & & & \\
\hline Hematite & 2 & 6 & & 1 & & \\
\hline Plagioclase & 3 & 4 & 13 & 9 & & 3 \\
\hline Cristoballite & & & 6 & 1 & & \\
\hline Pyrite & & & 1 & & & \\
\hline K-spar & & & 12 & & 2 & \\
\hline Anatase & & & & & 1 & \\
\hline Calcite & & & & & & 3 \\
\hline Total non-clays & 34 & 42 & 50 & 26 & 31 & 35 \\
\hline \multicolumn{7}{|l|}{ Clays } \\
\hline 2:1 dioctahedral clays & 46 & 34 & 36 & 74 & 62 & 62 \\
\hline Kaolinite & 8 & 15 & 14 & & 1 & 3 \\
\hline Chlorite-biotite & 12 & 9 & & & 6 & \\
\hline Total clays & 66 & 58 & 50 & 74 & 69 & 65 \\
\hline \multirow[t]{3}{*}{ Detailed clay analysis } & Smectite & Smectite & $\begin{array}{l}\text { Smectite with } \\
\text { interlayer complexes } \\
\text { (dominant phase) }\end{array}$ & Smectite & $\begin{array}{l}\text { Ordered illite-smectite } \\
\text { (dominant phase) }\end{array}$ & $\begin{array}{l}\text { Ordered illite-smectite } \\
\text { (dominant phase) }\end{array}$ \\
\hline & $\begin{array}{l}\text { Chlorite \& } \\
\text { chlorite-smectite }\end{array}$ & $\begin{array}{l}\text { Chlorite, } \\
\text { chlorite-smectite \& } \\
\text { corrensite }\end{array}$ & & & Kaolinite & Kaolinite \\
\hline & $\begin{array}{l}\text { Illite kaolinite \& } \\
\text { kaolinite-smectite }\end{array}$ & $\begin{array}{l}\text { Illite kaolinite \& } \\
\text { kaolinite-smectite }\end{array}$ & Kaolinite-smectite & & & \\
\hline
\end{tabular}

The table shows the results of the quantitative bulk analyses (in weight percentages) and a description of the clay mineralogy based on clay extraction procedures and identification techniques. Two samples were analysed per dominant lithology.

particles and physical disintegration of soil aggregates, thereby reducing surface infiltration and enhancing surface runoff (Agassi et al., 1981).

Our results of the rainfall runoff experiments point to the necessity of protecting surface vegetation cover and improving soil physical and chemical properties to avoid rapid surface sealing and crusting due to raindrop impact. Degraded land is characterized by a poor vegetative cover, and is affected by rapid generation of surface runoff, splash and water erosion. When bare, the clay-rich soil is prone to rapid dispersion of clay minerals, thereby reducing aggregate stability, accelerating surface sealing and crusting, limiting surface water storage and surface infiltration, and enhancing surface runoff and soil loss. In contrast to degraded land, arable land and rangeland generally have good vegetation cover and soil physical and chemical properties; but soil properties deteriorate rapidly by improper land management.

\subsection{Effect of land use and management on runoff generation}

Land use and vegetation cover strongly determine runoff generation on anthropogenic land (Table 2). Arable land and rangelands are characterized by low cumulative runoff coefficients $(4 \% \pm 4)$; whereas degraded and abandoned land display a large variation in cumulative runoff coefficients $(48 \% \pm 22)$ which mainly depend on their vegetation cover (Fig. 3), and soil organic matter.
Degraded land has a large variability in runoff rates, and shows high cumulative runoff coefficients (Fig. 4A). Cumulative runoff coefficients on degraded land range between 4 and 100\%, with an average value of $47 \%$. These degraded areas are characterized by soil truncation and often by outcrops of weathered bedrock. These structurally degraded soils limit soil biological activity and plant establishment by reducing plant root development and growth, and by reducing water and nutrient cycling and storage capacity (Wilcox et al., 1988; McGinty et al., 1995). Degraded land has generally a low vegetative cover $(18 \% \pm 23.5)$, and low soil organic matter content $(1 \% \pm 1)$. Consequently, they are prone to generate runoff, as their reduced vegetative cover enhances soil crusting and sealing, and their reduced infiltration capacity enhances runoff generation, and soil and nutrient losses (Thurow, 2000). More than half of the rainfall runoff experiments (i.e. 20 out of 37) on degraded land have a soil organic matter content and vegetative cover of less than $1 \%$ and $10 \%$ respectively, which give rise to very high runoff coefficients (57\% 16 ; Fig. 3$)$. Within degraded land, areas of sediment accumulation or afforested areas have an improved soil water holding capacity due to improved vegetative cover and soil texture. With increasing surface vegetation cover, runoff generation and sediment production decrease, as is often reported in the literature (e.g. Gyssels et al., 2005; Bochet et al., 2006) and which can be attributed to various factors such as the direct protective effect of the cover but also to the positive relationship between soil cover and organic matter content (Fig. 6). For the experiments conducted on degraded land 
with a vegetative cover of more than $25 \%$, the runoff coefficient was on average $36 \%$, roughly 1.5 times lower than the runoff coefficient on bare degraded land.

In contrast to degraded land, arable land and rangeland present very low cumulative runoff coefficients irrespective of the vegetation cover (Fig. 4A). The cumulative runoff coefficient on arable land varies from 0 to $13 \%$ with an average value of $5 \% \pm 4$, and on rangeland from 0 to $8 \%$ with an average value of $4 \% \pm 4$. Arable land is characterized by loamy soils, with a soil organic matter content ranging from 2 to $3 \%$ with an average value of $2 \% \pm 0.5$. The plant and residue cover of the plots at the time of the experiments (i.e. end of the growing season/beginning of harvest season) ranged from 7 to $74 \%$, with an average value of $26 \% \pm 26$. This large variability does not reflect the natural variability in surface cover of agricultural fields, but here only indicates the stage of land preparation (tillage, harvest) at the moment of the experiment. As soil physical and chemical characteristics are well maintained during the growing and harvesting season, we do not observe any dependency of the runoff coefficient on the vegetation cover on arable land (Fig. 3). The persistence of favourable soil conditions may be due to the large amount of residue cover that is left on the cropland after harvest and that is incorporated in the plough layer by tillage. McGinty et al. (1995) and Pellant (2000) describe how decomposing plant residue improves soil structure and stability, enhances surface infiltration and reduces runoff.

Rangeland is prevalent on sandy and clayey loamy soils. The studied plots have a soil organic matter content varying between 1 and $10 \%$ with an average value of $6 \% \pm 3$; and most rangeland areas are $100 \%$ covered with perennial grasses (such as $P$. clandestinum and Trifolium sp.). Perennial grasses directly and indirectly affect surface hydrology. They directly intercept rainfall, and retard surface runoff; and indirectly enhance infiltration by improving soil structure and maintaining active flow paths along macropores (Mills et al., 1992; Pellant, 2000).
Perennial grasses are an important source of organic matter of the uppermost soil horizons, and enhance the stability of soil aggregates by lowering their wettability and increasing their cohesion. Their root growth not only contributes to the development of macropores, which act as preferential flow paths and enhance deep infiltration and percolation, but also to the resistance of the soil to concentrated flow erosion. However, the sustainability of these rangelands is increasingly at risk. Overgrazing and trampling are leading to deterioration of its vegetation cover and compaction of its uppermost soil horizons, and are likely to reduce soil infiltration capacity and augment surface runoff (Vanacker et al., 2003b).

The hydrological properties of abandoned land resemble most those of degraded land (Fig. 4A). Cumulative runoff coefficients range between 28 and $90 \%$ with an average value of $55 \% \pm 24$. The soil organic matter of the runoff plots varies between 1 and $6 \%$, with an average of $3 \% \pm 2$, and the vegetation cover ranges from 28 to $88 \%$. Our results indicate that runoff generation on abandoned land is much higher than on arable land, and is clearly dependent of its vegetation cover (Fig. 3). Following fallow, the soil structure is deteriorating rapidly due to (i) sealing and crusting of the soil surface by raindrop impact in the absence of surface vegetation cover, and (ii) trampling and compaction of the upper soil horizons by grazing cattle. The link between land abandonment and degradation was already highlighted by Harden (1996). Her rainfall simulation experiments $(1993,1996,2001)$ in the Southern Ecuadorian Andes indicated the risk of abandoned land for rapid runoff generation and soil erosion.

\subsection{Runoff generation mechanisms and their effect on hillslope hydrology}

Understanding the runoff generation mechanisms on hillslopes is crucial to evaluate the impact of land use/-cover change on hydrological functions (e.g. Ceballos and Schnabel, 1998). In the

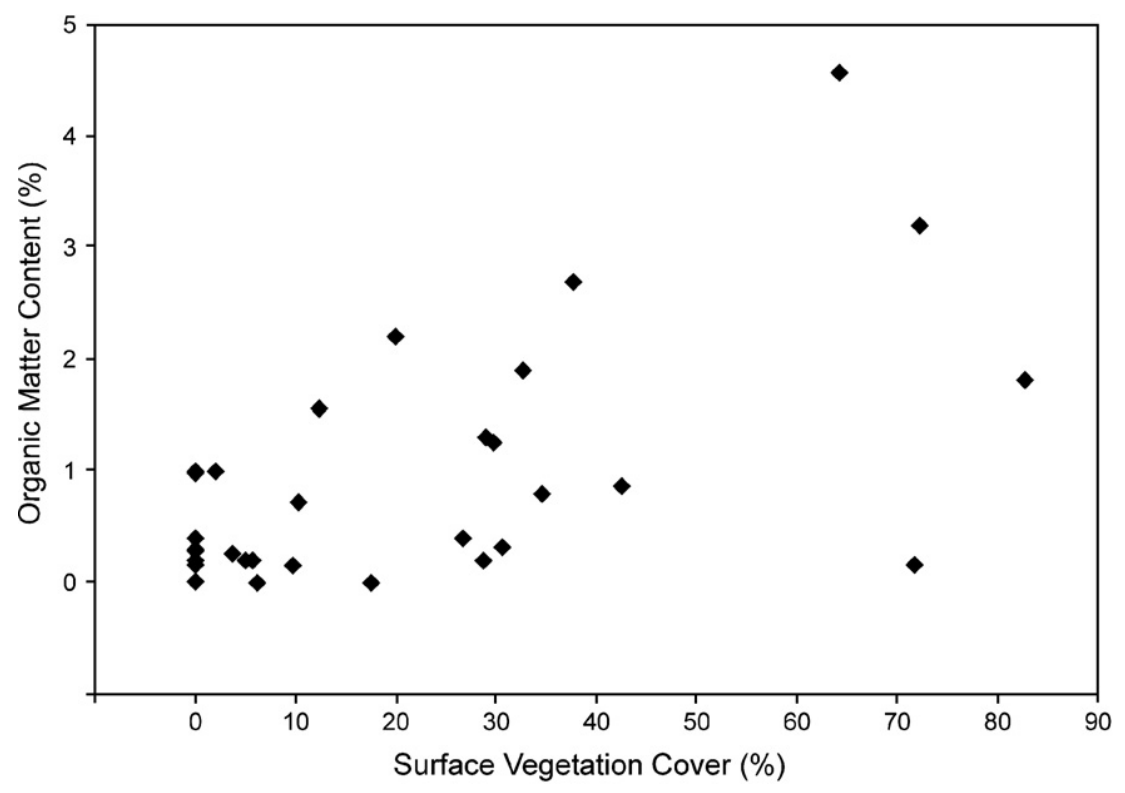

Fig. 6. Scatterplot of the soil organic matter content against the surface vegetation cover for degraded land. 


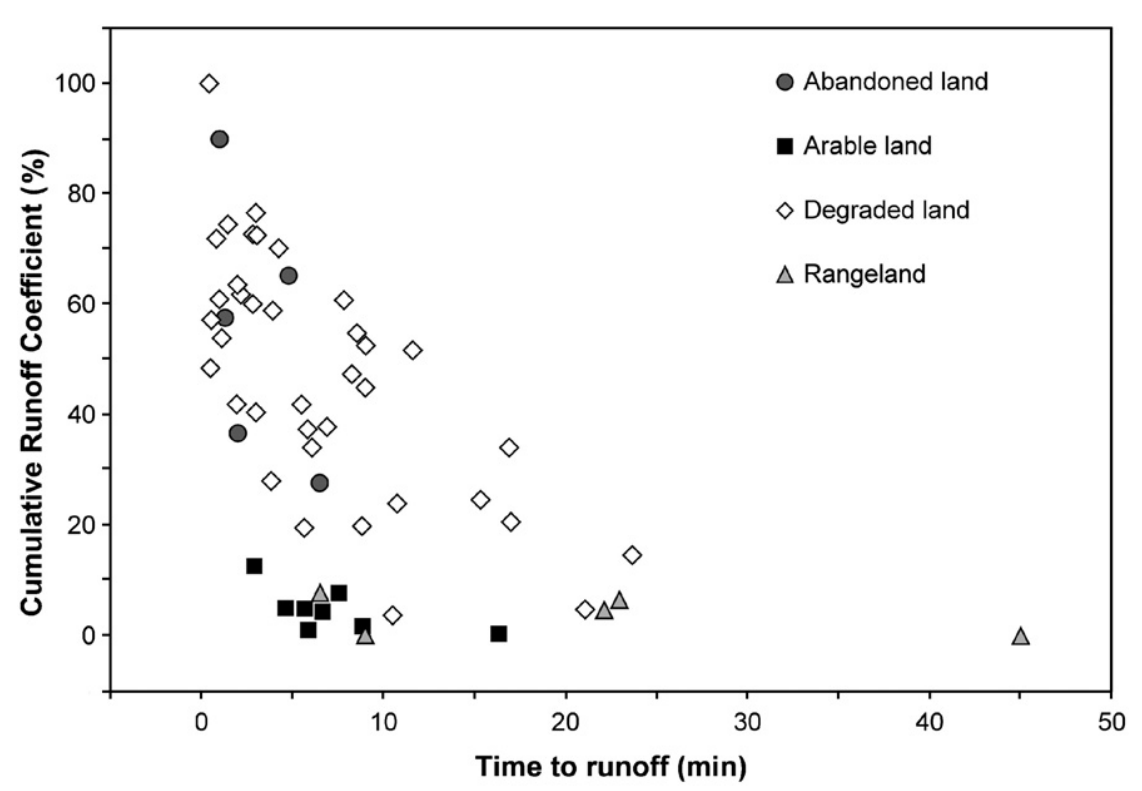

Fig. 7. Scatterplot of the cumulative runoff coefficient against the time to runoff for different land use types.

Jadan catchment, both Hortonian and saturation overland flow are responsible for runoff generation. On the slopes, rainfall water infiltrates and percolates directly to the water table or flows downslope through the soil mantle as throughflow (Whipkey, 1965; Guebert and Gardner, 2001). Saturation overland flow encompasses direct rainfall on saturated surfaces and throughflow that returns to the surface near the base of the slope as return flow (Dunne and Black, 1970). Whether Hortonian or saturation overland flow occurs depends on surface vegetation cover, soil development, and land management, and also on topography and lithology. Hortonian overland flow occurs when the rainfall intensity exceeds the infiltration capacity of the surface (Horton, 1933).
In the Jadan catchment, Hortonian overland flow is common on degraded and abandoned land. The infiltration capacity of both land use types is limited due to crusting and sealing of the structureless, shallow topsoil. Runoff generation on degraded and abandoned land is non-uniform in space and time. Their surface vegetation cover is very patchy, and behaves like a mosaic of runoff and runon areas (sources and sinks) similar to what is observed for Mediterranean environments (Cerdà i Bolinches, 1995; Bergkamp, 1998). Bare soil acts as a major source of runoff water. Its infiltration capacity is low, as the presence of smectites and the absence of any protective vegetation cover enhances sealing and crusting of the bare soil surface. Patches of vegetation act as sink areas for surface runoff (Calvo-Cases et al., 2003).

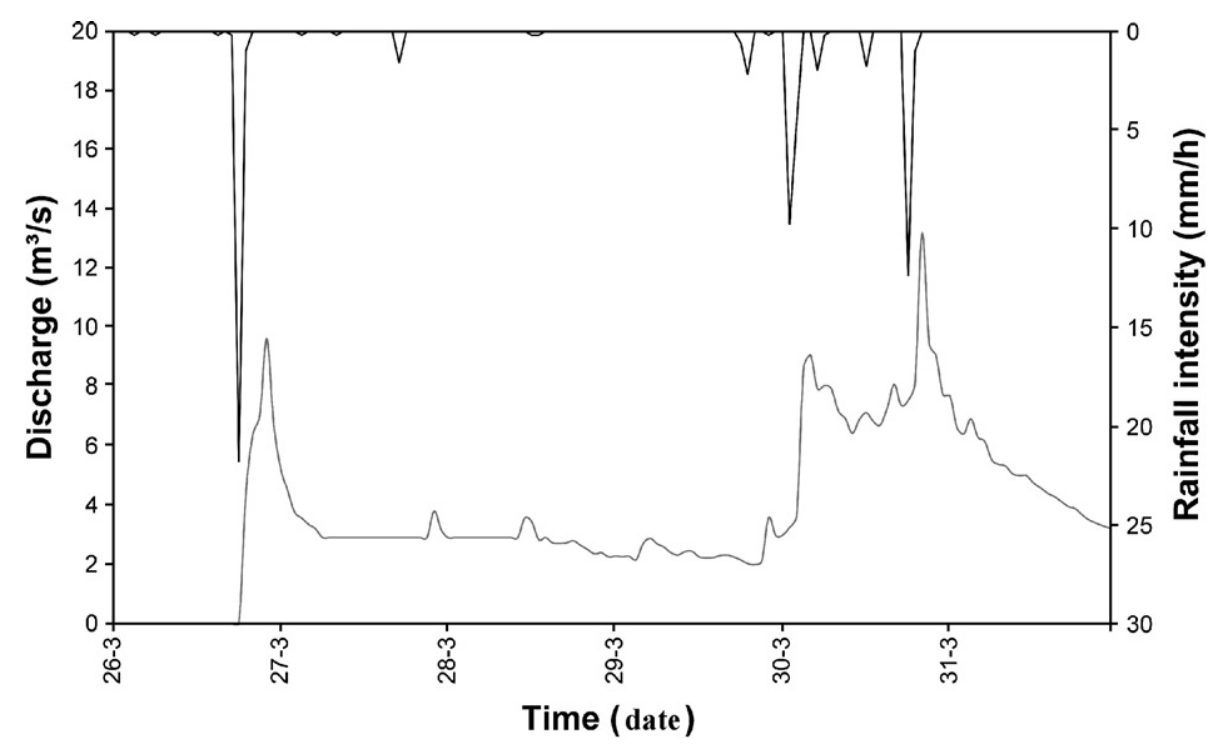

Fig. 8. The stream hydrograph shows how the discharge (bottom grey line) of the Jadan River, draining a highly degraded $296 \mathrm{~km}^{2}$ catchment, changed between March 26th and March 31st, 2005. Intense rainfall (upper black line), which occurred on March 26, 30 and 31, caused a rapid rise of the discharge in the Jadan River. 
They are often composed of small shrubs, such as Cynodon dactylon, Holcus lanatus, Cortaderia rudiuscula, Festuca megalura, Baccharis polyantha, P. clandestinum and Spartium junceum. Recovery of the surface vegetation cover by plant colonization or plantings improves the soil structure, enhances the soil infiltration capacity, and reduces runoff generation.

The hydrological response of large rivers will largely depend on the dominant runoff generation mechanisms in their catchment (Lopez-Moreno et al., 2006). Our runoff experiments indicate that degraded and abandoned land on mountain slopes have high runoff coefficients $(48 \% \pm 22)$. These areas are sensitive to rainfall events of short duration and high intensity, which are common in this mountainous region. Fig. 7 shows the relation between the runoff coefficient and the time to runoff for different land use types. The data on Fig. 7 clearly indicate that runoff generation on degraded and abandoned land is very rapid, and Hortonian overland flow generally starts within a few minutes after the start of the rainfall. This runoff water flows rapidly downslope through active gully systems, which increase the runoff connectivity and therefore contribute significantly to the peak flow discharge of the river systems. This rapid response of degraded and abandoned land explains why the peak runoff discharge in degraded catchments occurs shortly after the start of heavy rainfall events, after which a sharp and rapid recession of stream flow takes place (Fig. 8). This hydrological response brings about a rapid rise and drop in streamflow discharge causing severe floods downstream.

In contrast to degraded and abandoned land, cultivated or forested hill slopes preserve their vegetation cover and physical and chemical soil properties. Runoff generation by Hortonian overland flow is limited or simply not occurring, as our rainfall simulation experiments show low cumulative runoff coefficients and high infiltration rates (i.e. $>29 \mathrm{~mm} / \mathrm{h}$ ) in cultivated or forested areas. In such areas, the hillslope response to rainfall is expected to be much slower, and the hydrological response of the river system is also expected to be lower and slower (Fig. 7). This was also observed by Begueria et al. (2006), who have shown that the hydrological response of two contrasting basins in the Central Spanish Pyrenees is strongly depended on their land use history.

Land use change will therefore have a profound effect on the occurrence of Hortonian overland flow. In the Jadan catchment, increasing land degradation and/or land abandonment will lead to flashier hydrographs and probably higher peak discharges, while vegetation recovery on degraded or abandoned lands will lead to a decrease in peak discharges and runoff amounts. Such processes are indeed occurring: in the Jadan catchment, the area of degraded land with a poor vegetation cover changed from 3362 to 1893 ha between 1963 and 1996 (Molina et al., in press), probably leading to a corresponding reduction in peak discharges in the Jadan river. However, a direct, quantitative extrapolation of the results of our rainfall simulation experiments to the catchment scale is not possible: at larger scales, part of the runoff water may again infiltrate, e.g. in vegetated gullies. A quantitative assessment of hydrological changes in the Jadan catchment over a longer time span is therefore only possible when such transmission losses are also accounted for.
Our results also imply that it is not arable agriculture per se which is causing an increase in peak discharges and runoff amounts: arable land has very low runoff coefficients, even when the vegetation cover is low. This is explained by the favourable soil conditions that can be maintained on arable land (high porosity, infiltration and organic matter content). This is not a generally valid conclusion: in other areas in the Andes, where soils are structurally less stable, arable land does contribute significantly to runoff generation (De Noni et al., 2001). High runoff amounts are generated mainly on degraded and abandoned land: here the decrease in vegetation cover is not compensated for by favourable soil conditions achieved by intensive management. Runoff amounts do increase sharply with decreasing vegetation cover on degraded and abandoned land the absence of a protective vegetation cover is one of the main factors leading to increased runoff generation.

\section{Conclusion}

Rainfall simulation experiments indicate that runoff coefficients in the Southern Ecuadorian Andes are highly variable. Although accelerated runoff and erosion have commonly been related to agricultural activities, our results indicate that degraded and abandoned land are important sites of runoff generation, and generate more runoff than rangeland or arable land. The hydrological response on degraded and abandoned lands is rapid and sharp, as Hortonian overland flow is the dominant runoff generation mechanism. This is in strong contrast with arable and rangelands where Hortonian overland flow generation is very limited. The differences in response between various land use types imply that land use change will have a significant effect on the hydrological response of the Jadan catchment.

Univariate and multivariate regression techniques were performed to determine the factors controlling runoff generation. More than $60 \%$ of the observed variability in runoff generation can be explained by a combination of the surface vegetation cover and land use. When reducing the surface vegetation cover, the soil is increasingly affected by rapid hillslope runoff and erosion. The presence of large amounts of smectites in the outcropping rocks makes the surface material very prone to sealing and crusting, thereby enhancing runoff generation.

\section{Acknowledgements}

This work was supported by a fellowship of the KULeuven Interfaculty Council for Development Co-operation (IRO) to A.M., a fellowship of Institute for the Promotion of Innovation through Science and Technology in Flanders (IWT-Vlaanderen) to E.Z., and a postdoctoral fellowship of the Fonds de la Recherche Scientifique (FNRS) to V.V. The Flemish Interuniversity Council (VLIR-OI) supported the Inter-University Project "Towards integrated catchment management in tropical mountain areas: the problem of sediment management, Paute River, Ecuador" between the University of Cuenca, Ecuador and the K. U. Leuven, Belgium. Special thanks also go to S. Herremans, T. Smets, and C. Coello for their help and assistance with the rainfall simulation experiments. We also acknowledge M. Ramirez, 
E. Tacuri and Bert de Biévre (Programa Para El Manejo del Agua y del Suelo, University of Cuenca) for assistance with field and laboratory work. E.Z. wishes to thank Chevron ETC and Douglas $\mathrm{K}$ McCarty in particular for permitting to use the QUANTA proprietary software.

\section{References}

Agassi, M., Shainberg, I., Morin, J., 1981. Effect of electrolyte concentration and soil sodicity on the infiltration rate and crust formation. Soil Science Society of America Journal 45, 848-851.

Baculima, F.L., Baculima, J.C., Bermeo, W.A., 1999. Caracterización de clima por microcuencas en el Austro Ecuatoriano. Unpublished Eng. Thesis, Facultad de Ingenieria, Universidad de Cuenca, Cuenca, Ecuador.

Begueria, S., López-Moreno, J.I., Gómez-Villar, A., Rubio, V., Lana-Renault, N., García-Ruiz, J.M., 2006. Fluvial adjustments to soil erosion and plant cover changes in the Central Spanish Pyrenees. Geografiska Annaler. Series A. Physical Geography 88 A, 177-186.

Bergkamp, G., 1998. A hierarchical view of the interactions of runoff and infiltration with vegetation and microtopography in semiarid shrublands. Catena 33, 201-220.

Bochet, E., Poesen, J., Rubio, J.L., 2006. Runoff and soil loss under individual plants of a semi-arid Mediterranean shrubland: influence of plant morphology and rainfall intensity. Earth Surface Processes and Landforms 31, 536-549.

Burch, G.J., Bath, R.K., Moore, I.D., O’Loughlin, J.M., 1987. Comparative hydrological behaviour of forested and cleared catchments in southeastern Australia. Journal of Hydrology 90, 19-42.

Calvo-Cases, A., Boix-Fayos, B., Imeson, A.C., 2003. Runoff generation, sediment movement and soil water behaviour on calcareous (limestone) slopes of some Mediterranean environments in southeast Spain. Geomorphology 50, 269-291.

Casermeiro, M.A., Molina, J.A., de la Cruz Caravaca, M.T., Hernando Costa, J., Hernando Massanet, M.I., Moreno, P.S., 2004. Influence of scrubs on runoff and sediment loss in soils of Mediterranean climate. Catena 57, 91-107.

Ceballos, A., Schnabel, S., 1998. Hydrological behaviour of a small catchment in the dehesa landuse system (Extremadura SW Spain). Journal of Hydrology 210, 146-160.

Cerdà i Bolinches, A., 1995. Factores y Variaciones Espacio-Temporales de la Infiltración en los Ecosistemas Mediterráneos. Ediciones Geoforma, Logroño.

De Noni, G., Viennot, M., Asseline, J., Trujillo, G., 2001. Terres d'altitude, terres de risques - La lutte contre l'érosion dans les Andes équatoriennes. L'Institut de recherche pour développement, Paris, France.

Dercon, G., Bossuyt, B., De Bièvre, B., Cisneros, F., Deckers, J., 1998. Zonificación Agro-ecologica del Austro Ecuatoriano. Programa para el Manejo del Agua y Suelo (PROMAS), Cuenca, Ecuador.

Dunne, T., Black, R.D., 1970. An experimental investigation of runoff production in permeable soils. Water Resources Research 6, 478-490.

Garcìa-Ruiz, J.M., Arnàez, J., Beguerìa, S., Seeger, M., Martì-Bono, C., Regüès, D., Lana-Renault, N., White, S., 2005. Runoff generation in an intensively disturbed, abandoned farmland catchment, Central Spanish Pyrenees. Catena 59, 79-92.

Guebert, M.D., Gardner, T.W., 2001. Macropore flow on a reclaimed surface mine: infiltration and hillslope hydrology. Geomorphology 39, $151-169$.

Gurtz, J., Baltensweiler, A., Lang, H., 1999. Spatially distributed hydrotopebased modelling of evapotranspiration and runoff in mountainous basins. Hydrological Processes 13, 2751-2768.

Gyssels, G., Poesen, J., Bochet, E., Li, Y., 2005. Impact of plant roots on the resistance of soils to erosion by water: a review. Progress in Physical Geography 29, 189-217.

Harden, C.P., 1993. Land use, soil erosion, and reservoir sedimentation in an Andean drainage basin in Ecuador. Mountain Research and Development 13, 177-184.

Harden, C.P., 1996. Interrelationship between land abandonment and land degradation: a case from the Ecuadorian Andes. Mountain Research and Development 16, 274-280.
Harden, C.P., 2001. Soil erosion and sustainable mountain development. Experiments, observations, and recommendations from the Ecuadorian Andes. Mountain Research and Development 21, 77-83.

Horton, R.E., 1933. The role of infiltration in the hydrological cycle. American Geophysical Union Transactions 14, 446-460.

Hungerbühler, D., Steinmann, M., Winkler, W., Seward, D., Eguez, D., Eguez, A., Peterson, D.E., Helg, U., Hammer, C., 2002. Neogene stratigraphy and Andean geodynamics of southern Ecuador. Earth-Science Reviews 57, 75-124.

Jackson, M.L., 1975. Soil Chemical Analysis - Advanced Course, 2nd edition. Published by the author, Madison, Wisconsin.

Janeau, J.L., Bricquet, J.P., Planchon, O., Valentin, C., 2003. Soil crusting and infiltration on steep slopes in Northern Thailand. European Journal of Soil Science 54, 543-553.

Jokisch, B.D., Lair, B.M., 2002. One last stand? Forests and change on Ecuador's eastern Cordillera. Geographical Review 92, 235-256.

Lado, M., Ben-Hur, M., 2004. Soil mineralogy effects on seal formation, runoff and soil loss. Applied Clay Science 24, 209-224.

Lopez-Moreno, J.I., Begueria, S., Garcia-Ruiz, J.M., 2006. Trends in high flows in the central Spanish Pyrenees: response to climatic factors or to land-use change? Hydrological Sciences Journal 51, 1039-1050.

McGinty, A., Thurow, T.L., Taylor Jr., C., 1995. Improving Rainfall Effectiveness on Range Lands. Texas Agriculture Extension Service, Texas A \& M University, College Station, Texas.

Mills, W.L., Thomas, A.W., Langdale, G.W., 1992. Seasonal and crop effects on soil loss and rainfall retention probabilities: an example from the Southern Piedmont. Soil Technology 5, 67-79.

Molina, A., Govers, G., Poesen, J., Van Hemelryck, H., De Bièvre, B., Vanacker, $\mathrm{V}$., in press. Environmental factors controlling spatial variation in sediment yield in a central Andean mountain area. Geomorphology.

Moore, D.M., Reynolds, R.C., 1997. X-ray Diffraction and the Identification and Analysis of Clay Minerals. Oxford University Press, Oxford-New York.

Nahar, N., Govindaraju, R.S., Corradini, C., Morbidelli, R., 2004. Role of runon for describing field-scale infiltration and overland flow over spatially variable soils. Journal of Hydrology 286, 36-51.

Omotoso, O., McCarty, D.K., Hillier, S., Kleeberg, R., 2006. Some successful approaches to quantitative mineral analysis as revealed by the 3rd Reynolds Cup Contest. Clays and Clay Minerals 54, 748-760.

Pellant, M., 2000. Interpreting Indicators of Rangeland Health. Department of the Interior, BLM. National Science and Technology Center, Information and Communications Group. Denver, CO.

Poesen, J., Ingelmo-Sanchez, F., Mücher, H., 1990. The hydrological response of soil surfaces to rainfall as affected by cover and position of rock fragments in the top layer. Earth Surface Processes and Landforms 15, 653-671.

Poesen, J., Govers, G., Paulissen, E., Vandaele, K., 1995. A geomorphological evaluation of erosion risk at Sagalassos. Acta Archaeological Lovaniensia Monographiae 7, 341-356.

Price, M., 1999. Global Change in the Mountains. Parthenon Publishing Group, New York.

Środoń, J., Drits, V.A., McCarty, D.K., Hsieh, J.C.C., Eberl, D.D., 2001. Quantitative XRD analysis of clay-rich rocks from random preparations. Clays and Clay Minerals 49, 514-528.

Thurow, T.L., 2000. Hydrologic effects on rangeland degradation and restoration processes. In: Arnalds, O., Archer, S. (Eds.), Rangeland Desertification. Kluwer Academic Publishers, Dordrecht, pp. 53-66.

Vanacker, V., Govers, G., Barros, S., Poesen, J., Deckers, J., 2003a. The effect of short-term socio-economic and demographic changes on landuse dynamics and its corresponding geomorphic response with relation to water erosion in a tropical mountainous catchment, Ecuador. Landscape Ecology 18, 1-15.

Vanacker, V., Vanderschaeghe, M., Govers, G., Willems, E., Poesen, J., Deckers, J., De Biévre, B., 2003b. Linking hydrological, infinite slope stability and land use change models through GIS for assessing the impact of deforestation on landslide susceptibility in High Andean watersheds. Geomorphology 52, 299-315.

Vanacker, V., Molina, A., Govers, G., Poesen, J., Dercon, G., Deckers, S., 2005. River channel response to short-term human-induced change in connectivity in Andean ecosystems. Geomorphology 72, 340-353.

Viviroli, D., Weingartner, R., 2004. The hydrological significance of mountains: from regional to global scale. Hydrology and Earth System Sciences 8, 1016-1029. 
Viviroli, D., Weingartner, R., Messerli, B., 2003. Assessing the hydrological significance of world's mountains. Mountain Research and Development 23, 32-40.

Weingartner, R., Barben, M., Spreafico, M., 2003. Floods in mountain areas an overview based on examples from Switzerland. Journal of Hydrology $282,10-24$.
Whipkey, R.Z., 1965. Subsurface stormflow from forested slopes. Bulletin of the International Association of Scientific Hydrology 10, 74-95.

Wilcox, B.P., Wood, M.K., Thomble, J.M., 1988. Factors influencing infiltrability of semi arid mountain slopes. Journal of Range Management 41, 197-206. 